\title{
Energy valorization of integrating lipid extraction and hydrothermal liquefaction of lipid-extracted sewage sludge
}

\author{
Y. Fan ${ }^{\text {a, }}{ }^{*}$, F.G. Fonseca ${ }^{\text {a }}$, M. Gong ${ }^{\text {b }}$, A. Hoffmann ${ }^{\text {a }}$, U. Hornung ${ }^{\text {a, c }}$, N. Dahmen ${ }^{\text {a }}$ \\ ${ }^{a}$ Karlsruhe Institute of Technology, Institute of Catalysis Research and Technology (IKFT), Eggenstein-Leopoldshafen, Germany \\ ${ }^{\mathrm{b}}$ Hefei University of Technology, School of Civil Engineering, Hefei, PR China \\ ${ }^{\mathrm{c}}$ University of Birmingham, School of Chemical Engineering, Edgbaston, Birmingham, B15 2TT, United Kingdom
}

Keywords:

Sewage sludge

Lipid extraction

HTL

Biocrude

Energy

Energy consumption ratio

\begin{abstract}
A B S T R A C T
With the rapid growth in population and urbanization, a development in sustainable treatment of sewage sludge has become an urgent environmental concern globally. Lipid extraction has been inves tigated in order to valorize waste sewage sludge treatment through a pathway that leads to biodiesel. In this work, an integrated approach that combines lipid extraction of sewage sludge with hydrothermal liquefaction of the lipid extracted sludge was studied in order to maximize valorization. The hydro thermal process was performed at temperatures ranging from 250 to $350{ }^{\circ} \mathrm{C}$ with 20 min. Regarding the bio crude: below $300{ }^{\circ} \mathrm{C}$, similar values are found with and without lipid extraction, with the former variant containing more nitrogenated compounds stemming from Maillard reactions, while the latter more hydrocarbons; at $350{ }^{\circ} \mathrm{C}$, higher bio crude is obtained from raw sewage sludge owning to the conversion of lipids. Palmitic acid was selected as a model lipid to elucidate the role of lipids during the process, as well as to provide an improved understanding of the reaction network. Energy recovery reached values of $85.4 \%$ for hydrothermal liquefaction of sewage sludge and $98.3 \%$ for integrated approach considering the whole range of biofuel products. The energy consumption ratio was applied to estimate energetic efficiency for the combined process, making it possible to estimate the breakeven point of the process, plus the efficiency of both the hydrothermal process on its own in comparison with the combined option.
\end{abstract}

\section{Introduction}

Regarding sewage sludge (SS), a multitude of technologies has been proposed to substitute traditional ways of disposal. Research has reported that landfills, composting and combustion not only waste material but also create environmental problems (Cai et al., 2004; Syed Hassan et al., 2017). In addition, initiatives for the reduction of $\mathrm{CO}_{2}$ emissions drive society to find alternative sources to supply an ever increasing demand for fuel products, providing an opportunity to view sewage sludge, not as a waste, but rather as a source of carbon and energy. Therefore, sewage sludge is considered a very promising waste feedstock, due to its availability, as well as to its organic matter and nutrient contents (Gherghel et al., 2019; Peccia and Westerhoff, 2015).

In order to meet the globally growing energy demand and

\footnotetext{
* Corresponding author.

E-mail address: yujie.fan@partner.kit.edu (Y. Fan).
}

support climate mitigation strategies, the attention to make energy recovery from widespread waste has been increasingly paid to disposal of sewage sludge. Biodiesel production from SS is increased in recent years, because the production of biodiesel from vegetable oils has faced shortcomings associated with high feed stock prices, and competition with edible crops for arable land use has limited the expansion of production capacity (di Bitonto et al., 2020; Kwon et al., 2012). Sewage sludge may be considered a cost effective alternative due to its availability and lipid content, typi cally in the range of $20 \mathrm{wt} \%$ (dry ash free basis) (Zhu et al., 2014); the lipid extraction potential can reach up to $12 \mathrm{wt} \%$ of the dry sludge (Supaporn and Yeom, 2016). The lipid content present in sewage sludge typically consists of free fatty acids in the range of C10 to C18 as precursors for the production of esters (typically methyl esters, FAME) (Siddiquee and Rohani, 2011). Different methodologies can be applied for the conversion and extraction of lipids from sewage sludge. Lipids may be extracted using conven tional liquid liquid methods from raw sludge prior to methanolysis, or the reaction can take place directly on dry sludge or dewatered 
sludge. Assuming an overall yield of FAMEs of $7.0 \mathrm{wt} \%$ with respect to the dry sludge, Dufreche et al. (2007) reached a breakeven price of $0.83 \$ \cdot \mathrm{L}^{-1}$, for which drying the dewatered sludge (80-85 wt\% water) was considered the most energy and cost demanding step. Mondala et al. (2009) estimated the price of biodiesel to be 0.85 $\$ \cdot \mathrm{L}^{-1}$ from in situ transesterification of dewatered sludge at an assumed yield of $10 \%$ FAMEs/dry weight of sludge. Pokoo Atkins et al. (Pokoo Aikins et al., 2010) reported a value of $0.76 \$ \cdot \mathrm{L}^{-1}$, by extracting lipids from the dry sludge prior to methanolysis. These values are comparable to those reported for petro diesel and show the high potential of sewage sludge as a competitive lipid source for the production of biodiesel.

Recently, research is being focused on the performing extraction of lipids from wet sludge that avoids energy intensive drying steps. Pastore et al. (2013) carried out hexane extraction directly on dewatered sludge followed by methanolysis of extracted lipids, reaching to $18 \mathrm{wt} \%$ FAMEs with the lowest energy demand $17 \mathrm{MJ} \mathrm{kg}^{-1}$. Olkiewicz et al. (2014) porposed the direct sequential liquid-liquid extraction using hexane for lipids is feasible and compares well with those classical pre drying methods, $27 \%$ (dry sludge) lipids ws obtained under the optimized extraction. Kech et al. (2018) further tested the extracting efficiency of different solvents to the direct lipid lipid extraction of lipids for biodiesel production, alternative solvents including cyclohexane/isopropyl alcohol improved the yields of lipids. However, the residual sludge (lipid extracted sewage sludge, LESS) must be effectively employed to achieve favorable energy balances and production costs.

During the last decade, hydrothermal liquefaction (HTL) is considered one of the most promising technologies, as it is able to convert high moisture feedstocks to an energy dense liquid bio crude, which could be further refined into transportation fuels. (Fox et al., 2019; Kruse and Dahmen, 2018). HTL typically takes place at medium temperature ranges from $250{ }^{\circ} \mathrm{C}$ to $370{ }^{\circ} \mathrm{C}$, the operating pressure is between 4 and $22 \mathrm{MPa}$, and reaction time 10-60 min (Rao et al., 2018). The yields of biocrude from sewage sludge are influenced by operation parameters, type of catalysts and solvents. From previous studies of sewage sludge using HTL, the biocrude produced varies from 10 to 48 wt\% (Qian et al., 2017; Suzuki et al., 1988; Wang et al., 2018). Currently, some physical and chemical methods for sewage sludge pre treatment were studied. Chen et al. (2020) explored the influence of microwave power on yield and composition of bio crude from HTL of SS, where increasing the microwave power can improve the biocrude yields by between 2 and $10 \%$. Kapusta (2018) reported that the ultrasound pretreatment can achieve $19 \%$ increase bio crude from HTL of SS $320^{\circ} \mathrm{C}$ compared with un treated sludge. Co liquefaction SS with other types of feedstocks has attracted considerable research interest as it aims to increase biocrude yield with improving quality (Yang et al., 2019). Fox et al. (2019) conducted the hydrothermal co liquefaction of food waste and SS after $200{ }^{\circ} \mathrm{C}$ pretreatment. To the best of our knowledge, limited information is available considering the inte gration of HTL and lipid extraction. Based on the success in using LESS as anaerobic digestion feedstock (Olkiewicz et al., 2014), and the proven feasibility of using lipid extracted algae residue (Frank et al., 2012; Shahi et al., 2020; Vardon et al., 2012) and de oiled yeast (Chopra et al., 2019) in HTL, the integration of both these processes is attractive due to the maximum utilization of sewage sludge, as well as the different products obtainable. When dis regarding the water content, LESS is mostly comprised of proteins and carbohydrates. In particular, proteins have been confirmed to promote to bio crude production using HTL (Posmanik et al., 2017). Maillard reactions play a significant role in the bio crude product distribution and composition, which is caused by the reaction of amine groups present in proteins with carbonyl groups present in reducing carbohydrates (Fan et al., 2018; Zhang et al., 2016).
Therefore, the objectives of this paper are: 1) to quantify and characterize the extracted lipids from sewage sludge and to eval uate their applicability for biodiesel production; 2) to investigate the hydrothermal conversion efficiency of LESS through HTL, comparing the different products generated by HTL of SS and LESS in order to evaluate whether LESS can be a potential feedstock for the production of fuel components; 3 ) to reveal the effect of lipids on bio crude products based on model compounds with an improved understanding to reaction pathways; 4) to estimate the coupling effect of lipids extraction and HTL of LESS, in terms of the yields of fuel like products and process efficiency.

\section{Materials \& methods}

\subsection{Materials}

Digested sewage sludge (SS) was obtained from a wastewater treatment plant (WWTP) in Plieningen, Stuttgart, Germany. The SS sample was collected from the WWTP and stored at $18{ }^{\circ} \mathrm{C}$ until use. The sludge was used directly as received (moisture content $78.75 \mathrm{wt} \%$ ) in this work. Crude protein was determined by Kjeldahl method, carbohydrates was determined by using the phenol sulfuric acid photometric estimation by DuBois method (Jimenez et al., 2013).

Methanol, sodium bicarbonate, sodium chloride, and palmitic acid (PA) were supplied by Sigma Aldrich, analytical grade. Supelco 37 Component FAME Mix used as a standard solution was pur chased from Restek. The same supplier provided HPLC grade dichloromethane (DCM), tetrahydrofuran, and hexane.

\subsection{Lipid extraction and quantification}

Extraction was carried out in a Soxhlet apparatus using hexane mixed with ethanol as a solvent (1:1 vol\%) (Zhu et al., 2014). For practical operation, $5 \mathrm{~g}$ of dried sample were poured in the thimble and $90 \mathrm{ml}$ solvent mixture was placed in the still pot. Extraction was performed at a temperature that ranged from 70 to $80{ }^{\circ} \mathrm{C}$ and sustained for about $6 \mathrm{~h}$. After extraction, the mixed solvent was removed using a rotary evaporator at $40{ }^{\circ} \mathrm{C}$ under vacuum at 50 mbar. Then, the remnant lipid fraction was stored in a desiccator overnight and weighed the next day to determine the extraction yield. The left residual was air dried and defined as lipid extracted sewage sludge (LESS).

In situ transesterification of sewage sludge was conducted by reactive extraction by adapting the method presented by Mondala et al. (2009), which goes as follows: $2 \mathrm{~g}$ of freeze dried sludge was weighed into a $250 \mathrm{ml}$ flask. The sludge samples were then treated

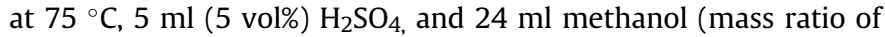
methanol to dried sludge $(12: 1)$ ). $25 \mathrm{ml}$ of hexane was added to improve the lipid solubility in the reaction mixture. The sludge was then suspended in a solution using a magnetic stirring bar and the mixture was heated to the set temperature using a hot water bath with a retention time of $8 \mathrm{~h}$. After the reaction was stopped, the mixture was allowed to cool, and the flask contents were trans ferred into a $100 \mathrm{ml}$ bottle. Then, $2.5 \mathrm{ml}$ of saturated $\mathrm{NaCl}$ solution and $25 \mathrm{ml}$ of hexane were added. The mixture was then centrifuged at $3000 \mathrm{rpm}$ for $3 \mathrm{~min}$ and the supernatant hexane phase was withdrawn and transferred into a $100 \mathrm{ml}$ round bottom flask. The extraction procedure was repeated three times. Afterward, the total volume of the collected supernatant was washed with $5 \mathrm{ml}$ of a $2 \%$ $(\mathrm{w} / \mathrm{v})$ sodium bicarbonate solution and the aqueous phase was allowed to settle. The upper layer passed through a filter paper containing anhydrous sodium sulfate before being collected.

FAME content in the hexane phase was analyzed using a Shi madzu GC FID (Agilent 7890 B). A Stabilwax DA, 
$30 \mathrm{~m} \times 0.25 \mathrm{~mm} \times 0.25 \mathrm{~mm}$ column was used for the analysis. The column temperature was programmed to start at $40{ }^{\circ} \mathrm{C}$, to be maintained for $10 \mathrm{~min}$, and then to be increased from 40 to $250{ }^{\circ} \mathrm{C}$ for $10 \mathrm{~min}$ at $8^{\circ} \mathrm{C} / \mathrm{min}$. The sample injection volume was $1.0 \mu \mathrm{l}$, with a split ratio of 10:1. Injection of standard solutions (Supelco 37 Component FAME Mix) with distinct concentrations and exami nation of the linear regression of the responses aided determina tion of the linearity. For example, the linear correlation coefficients were 0.99857 for palmitic acid (C16:0) (y $0.87773489 \times-$ 14.148712) and 0.99876 for stearic acid (C18:0) (y $0.88245915 \times$ $-8.9711545)$. Construction of the analytical curves enabled us to describe the mathematical equations used for quantitation and calculations.

\subsection{Hydrothermal liquefaction}

Each sample was liquefied in micro autoclaves with a volume of $24.5 \mathrm{ml}$ made of stainless steel $(1.4571 \mathrm{Ti})$, which can withstand pressures of up to $40 \mathrm{MPa}$ and a maximum temperature of $400{ }^{\circ} \mathrm{C}$.The reactors were loaded with sludge slurry, $25 \mathrm{wt} \%$ (dry free basis). It should be noted that the lipid extracted sludge was mixed with water to achieve similar conditions to dewatered sludge. For the case of palmitic acid, each batch consisted of $10 \mathrm{wt} \%$. The micro autoclaves were flushed to remove the undesired air and then pressurized to $2 \mathrm{MPa}$ using nitrogen gas. Heating was per formed in a gas chromatography (GC) furnace at a heating rate of $40 \mathrm{~K} / \mathrm{min}$ and kept at the target temperature $\left(250,300\right.$, or $\left.350^{\circ} \mathrm{C}\right)$ for $20 \mathrm{~min}$. After the reaction, the autoclaves were taken out of the oven and put in cold water to cool down and to stop the reaction. All the experiments were executed in triplicates to assess standard deviation (error bars in figures).

\subsubsection{Product separation and analysis}

After the HTL reaction, the micro autoclaves were opened in a gas tight containment after flushing air out using nitrogen. The gas composition was measured by manually injecting $100 \mu \mathrm{l}$ of the gas sample in an Agilent 7890 A gas chromatograph (equipped with a $2 \mathrm{~m}$ Molsieve 5 A and $2 \mathrm{~m}$ Porapak Q column). The mixed products including aqueous phase, bio crude and solid residue were washed with dichloromethane (DCM) and filtered through vacuum filtra tion using a Whatman nylon membrane $(47 \mathrm{~mm}, 0.45 \mu \mathrm{m}$ pore size). Most of the bio crude remained stuck to the micro autoclave walls after the reaction, so additional use of DCM was required to maximize the recovery of products. The solid residue remaining in the filter was placed in an oven and dried overnight at $105^{\circ} \mathrm{C}$ to determine the dry weight. The biphasic mixture obtained (aqueous product plus bio crude) was centrifuged and separated. The organic solvent was evaporated by flushing with nitrogen for $24 \mathrm{~h}$. Once a constant weight had been achieved, it was recorded and considered as the bio crude mass.

The $\mathrm{C}, \mathrm{H}$, and $\mathrm{N}$ contents of the bio crude and the solid residue were measured using a Vario EL III analysis system (Elementar Analysensysteme GmbH, Hanau, Germany). Oxygen content was calculated by difference.

GC MS analysis of bio crude was carried out using an Agilent $6890 \mathrm{~N}$ gas chromatograph with an Agilent 5973 MSD mass spec trometry detector and a DB 5 capillary column $(30 \times 0.25 \mathrm{~mm} \times 0.25 \mu \mathrm{m})$ after diluting with tetrahydrofuran $(1: 1 \mathrm{ml} / \mathrm{ml})$ and filtering with a $0.20 \mu \mathrm{m}$ polytetrafluoroethylene (PTFE) Filter. The substances were identified using the NIST library, considering only molecules with a match quality above $80 \%$. The amount of the different compounds was estimated by the relative area percentage method.

Thermal gravimetric analysis (TGA, Mettler toledo DSC 822) approximately $10 \mathrm{mg}$ of the samples was measured within the range from 20 to $800{ }^{\circ} \mathrm{C}$ with a heating rate of $10 \mathrm{~K} / \mathrm{min}$ and $\mathrm{N}_{2}$ flow rate of $50 \mathrm{ml} / \mathrm{min}$, to apply a method devised by Liu et al. (2018) for the assessment of the fractionation potential of produced bio crude in a petroleum refinery environment. The total carbon (TC), total organic carbon (TOC), total inorganic carbon (TIC), and total nitro gen $(\mathrm{TN})$ in the aqueous phase were measured with a Dimatec ${ }^{\circledR}$ 2100 instrument. Ammonium $\left(\mathrm{NH}_{4}^{+}\right)$, nitrate $\left(\mathrm{NO}_{3}^{-}\right)$, and nitrite $\left(\mathrm{NO}_{2}^{-}\right)$were investigated by Metrohm 838 advanced sample pro cessor device. Organic acids were analyzed with an Aminex HPX 87H column (Biorad, Hercules, CA, USA).

\subsection{Data definition}

The yields $\left(Y_{i}\right)$ of the different product fractions were calculated as the weight of the recovered mass of organic matter in the product $\left(O M_{i}\right)$ related to the total mass of organic matter in the feedstock $\left(\mathrm{OM}_{\text {feed }}\right.$, daf.), see Eq. (1).

Product Yields (wt. \%) $\frac{O M_{i}}{O M_{\text {feed }}} \times 100$

The HTL conversion efficiency was calculated as the difference in feedstock mass $\left(\mathrm{OM}_{\text {feed }}\right)$ and solid residue $\left(O M_{S R}\right)$ (assuming this to be unconverted feedstock) related to the feedstock mass $\left(\mathrm{OM}_{\text {feed }}\right)$, as shown in Eq. (2).

HTL conversion efficiency (\%) $\frac{O M_{\text {feed }}}{O M_{\text {feed }}} \times 100$

The elemental distribution, namely carbon distribution (CD) and nitrogen distribution (ND) are defined as the amount of an element in the product $\left(m_{E i}\right)$ relative to the amount in the feedstock product $\left(m_{\text {Efeed }}\right)$, see Eq. (3).

Elemental Distribution (wt. \%) $\frac{m_{E i}}{m_{E f e e d}} \times 100$

Higher heating value $\left(\mathrm{HHV} ; \mathrm{MJ} \cdot \mathrm{kg}^{-1}\right.$ ) was estimated using the modified Dulong's formula (Posmanik et al., 2017) as given in Eq. (4).

$H H V(M J / k g) \quad 0.0338 \times C+1.428(H \quad O / 8)$

The energy recovery (ER) as the sum of the higher heating values $\left(H H V_{i}\right)$ of the recovered fuel like products (bio crude, bio char, when necessary, extracted lipids) weighed by their yield $Y_{i}^{*}$ relative to the value $\left(H H V_{\text {feed }}\right)$ of the dry feedstock, see Eq. (5).

$E R(\%) \quad \frac{\Sigma\left(Y_{i}^{*} \times H H V_{i}\right)}{H H V_{\text {feed }}} \times 100$

The concept of ECR (Energy Consumption Ratio, Eq. (6)), was employed by Sawayama et al. (1999) and Minowa et al. (1998) to estimate the energetic viability of the process by relating the heat demands of the process to the heating value of the products. Values lower than 1 indicate a good energetic balance, revealing that the energy content of the products $\left(E_{0}\right)$ is higher than the energy requirement of the production process $\left(E_{L}\right)$.

ECR $\frac{E_{L}}{E_{0}}$

For the case of hydrothermal liquefaction, the authors propose the following formula (Eq. (7)), for which $w_{i}$ is the water content, $c_{p, w}$ is the specific heat of liquid water $\left(4.18 \mathrm{~kJ} \mathrm{~kg}^{-1} \cdot \mathrm{K}^{-1}\right), c_{p, s}$ is the specific heat of dry solid $\left(1.25 \mathrm{~kJ} \mathrm{~kg}^{-1} \cdot \mathrm{K}^{-1}\right), \Delta T$ is the temperature difference to ambient temperature $\left(25^{\circ} \mathrm{C}\right), Y_{i}$ is the product yield 
(wt.\% daf.), and $w_{0}$ is the organic fraction of the feedstock sludge (wt.\% daf.).

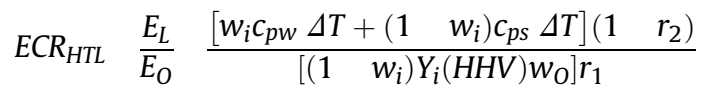

For the complete process chain, the concept of ECR was extended to additional process steps (Eq. (8)), which make use of heat demands $\left(Q_{i}\right)$ and product energy potentials $\left(E_{i}\right)$. Four different process configurations were considered: 1) HTL to produce only bio crude $\left(E C R_{B C}\right)$, which employs $\mathrm{Q}_{\mathrm{HTL}}$ and $\left.\mathrm{E}_{\mathrm{BC}} ; 2\right) \mathrm{HTL}$ to produce bio crude and solid residue as energy carriers $\left(E C R_{B C+S R}\right)$, which employs $Q_{H T L}, E_{B C}$, and $E_{S R} ; 3$ ) considering HTL products and lipid extraction ( $\left.E_{C} R_{B C+S R+L}\right)$, which employs $Q_{H T L}, Q_{\text {drying, }} Q_{\text {extraction, }} E_{B C}$, $E_{S R}$, and $E_{\text {LIPID }}$; 4) considering HTL products and FAME production from the lipids extracted $\left(\mathrm{ECR}_{\mathrm{BC}+\mathrm{SR}+\mathrm{FAME}}\right)$, which employs $\mathrm{Q}_{\mathrm{HTL}}$,

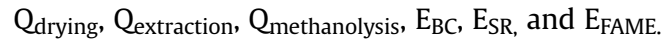

ECR $\quad \frac{E_{L}}{E_{O}} \frac{\left(\sum Q_{s t e p}\right)\left(1 \quad r_{2}\right)}{\left(\sum E_{\text {product }}\right) r_{1}}$

The efficiency of combustion $\left(r_{1}\right)$ and the efficiency of heat re covery $\left(r_{2}\right)$ can be adjusted depending on the technology employed. Sawayama et al. (1999), in 1999, used values for $r_{1}$ and $r_{2}$ of 0.6 and 0.5 , respectively. On the other hand, more up to date values of 0.7 and 0.5 have been proposed by Vardon et al. (2012) and an opti mized hypothetical case using state of the art combustion and heat recovery technology may permit reaching values of 0.9 and 0.6 (Demirbas, 2009). The latter two situations are considered during the discussion of results, and are named the case A and case B, respectively. As per Eq. (9) (Sawayama et al., 1999), $Q_{H T L}$, the heating demand of the hydrothermal liquefaction process was estimated as the sensible heat required to increase the temperature $(\Delta T)$ of the mixture (water + dry sludge) to the target temperature. No phase change was assumed to take part during the HTL process.

$Q_{H T L} \quad w_{i} c_{p w} \Delta T+\left(\begin{array}{ll}1 & w_{i}\end{array}\right) c_{p s} \Delta T$

For the case of drying (Eq. (10)), a final temperature of $100{ }^{\circ} \mathrm{C}$ was assumed with $\Delta H_{v a p, w}$ as the heat of vaporization of water (2.26 $\mathrm{MJ} \mathrm{kg}^{-1}$ ) and $H H V_{s}$ as the higher heating value of the sludge.

$Q_{\text {drying }} \quad\left[w_{i}\left(\Delta H_{v a p, w}+c_{p w} \Delta T\right)+\left(\begin{array}{ll}1 & w\end{array}\right) c_{p s} \Delta T\right]$

Qextraction was assumed to be $60.95 \mathrm{MJ} \cdot \mathrm{kg}^{-1}$ lipid taken from Olkiewicz et al. (2012), and a value of $934 \mathrm{Btu} / \mathrm{lb}\left(2.17 \mathrm{MJ} \mathrm{kg}^{-1}\right.$ ) was obtained for the demand of the methanolysis process ( $Q_{\text {methanolysis }}$ ) given by Huo et al. (2009). A value of $39.5 \mathrm{MJ} \mathrm{kg}^{-1}$ was assumed as the heat of combustion of FAME (Pastore et al., 2013).

The specific energy demand (ED, Eq. (11)) serves as another indicator of the energetic efficiency of the process, in such a way that it can be compared to other values reported in the literature or to other processes. It was calculated using both FAME and bio crude as mass basis, due to being the products of main interest.

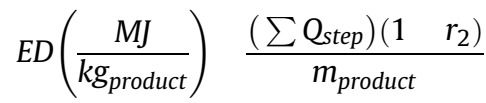

\section{Results}

\subsection{Feedstock composition}

The properties of sewage sludge (SS) and lipid extracted sludge (LESS) are outlined in Table 1. Protein was found to be the predominant fraction, accounting for $34.6 \mathrm{wt} \%$ and $38.9 \mathrm{wt} \%$ in sewage sludge and lipid extracted sludge respectively. which lays within the range available in the literature (30-60 wt\%) (Gao et al., 2020), including raw primary sludge, secondary sludge, and digested sludge. The results were quite consistent after 5 runs with 10 parallel repetitions each. Lipids were found to be a minor component of sludge, constituting $13.9 \mathrm{wt} \%$ of the raw material.

Elemental analysis was also displayed in Table 1 . Special care must be given to the nitrogen content in the feedstock, as this is an important control parameter for the quality of bio crude, due to the formation of NOx during combustion and demanding treatment during bio crude upgrading. However, protein rich sludge may still be desirable because of the higher thermochemical bio crude conversion efficiencies compared to those obtained with biomass that is richer in more recalcitrant carbohydrates and lignin (Vardon et al., 2012). Raw sludge showed a slightly higher energy content due to its lipids content.

Regarding lipid extraction, many methods with different pro cedures can be found in publications, of which a summary is pro vided in Table 2 below. Generally, Soxhlet extraction is quite effective in extracting lipids from both dry and wet sludge (Zhu et al., 2014) (Inoue et al., 1996) (Olkiewicz et al., 2014) (Boocock et al., 1992). It was assumed that all lipids present in the original material were extracted. The organic material was analyzed for carbohydrate, protein and lipid content, others may include lignin and fiber content.

\subsection{Lipid extraction from sewage sludge}

The fatty acid composition of the lipids from the SS was inferred from the results of the FAMEs produced by the in situ trans esterification of dry sludge samples. In Fig. 1, it can be clearly seen that a significant amount of methyl esters belong to relatively short chains below $\mathrm{C} 18$, the cumulative amount of $\mathrm{C} 16: 0$ and $\mathrm{C} 18: 1$ was more than $70 \%$, which was similar to the value in another report (Olkiewicz et al., 2014). The results show a predominance of pal mitic acid (C16:0), stearic acid (C18:0), oleic acid (C18:1), in line with previous work. Specifically, palmitic acid was the major saturated fatty acid with a value of $16.4 \%$, followed by stearic acid accounting for $8.9 \%$. Oleic acid was the major unsaturated fatty acid, followed by docosahexaenoic acid (C24:1). These fatty acids are exceptionally well suited for the production of biodiesel (Olkiewicz et al., 2012; Siddiquee and Rohani, 2011; Zhu et al., 2014).

\subsection{HTL of residue from lipid extracted sewage sludge (LESS)}

In this chapter, raw sewage sludge is used as "reference" to compare the hydrothermal conversion and the products obtained from the HTL of SS and LESS.

\subsubsection{HTL conversion}

A general comparison between the HTL of SS and LESS is shown in Fig. 2, where BC, SR and AQ represent the bio crude, solid residue and aqueous phases, respectively. Both HTL conversion efficiency (see Eq. (2)) and bio crude yield increase with the temperature for either feedstock, although HTL of SS shows higher conversions than HTL of LESS for the same operating conditions. Compared to results (average $25 \mathrm{wt} \%$ ) reported by other studies using similar operating conditions, the bio crude yields reported in this manuscript are lower (Liu et al., 2018; Suzuki et al., 1988). At $250^{\circ} \mathrm{C}$ and $300^{\circ} \mathrm{C}$, the yields of biocrude obtained from HTL of SS and LESS are basically the same; however, a difference occurs at $350{ }^{\circ} \mathrm{C}$, where the bio crude yields reach values of 21.3 and $15.4 \mathrm{wt} \%$ for SS and LESS, respectively. In contrast, the SR decreases with the reaction tem perature. Compared to HTL of LESS, HTL of SS results in lower solid 
Table 1

Characterization of sewage sludge and lipid-extracted sludge.

\begin{tabular}{|c|c|c|c|c|c|c|c|c|c|c|c|}
\hline \multirow[t]{2}{*}{ feedstock } & \multicolumn{4}{|c|}{ Biochemicals (wt.\% daf) ${ }^{\mathrm{a}}$} & \multirow[t]{2}{*}{ Ash } & \multicolumn{5}{|c|}{ Elemental content (wt.\%) } & \multirow{2}{*}{$\frac{\mathrm{HHV}}{\left(\mathrm{MJ} \$ \mathrm{~kg}^{1}\right)}$} \\
\hline & carbohydrates & Proteins & Lipids & others & & $C$ & $\mathrm{H}$ & $\mathrm{O}^{\mathrm{c}}$ & $\mathrm{N}$ & $\mathrm{S}$ & \\
\hline SS & 27.9 & 34.6 & 13.9 & 23.6 & 38.6 & 25.8 & 4.6 & 26.6 & 3.7 & 0.7 & 10.5 \\
\hline LESS & 31.3 & 38.9 & $\mathrm{e}$ & 29.8 & 45.3 & 24.0 & 4.1 & 22.2 & 3.8 & 0.6 & 10.0 \\
\hline
\end{tabular}

a On the ash-free basis.

b On the dry basis.

c Calculated by difference to the total mass.

Table 2

Summary of lipid extraction from published sources.

\begin{tabular}{|c|c|c|c|c|}
\hline Feedstocks & Fractions & Content wt.\% (db) & Methods (solvent) & Reference \\
\hline $\begin{array}{l}\text { Primary mixed waste activated sludge Digested } \\
\text { sludge }\end{array}$ & Crude fat & 10.4 & $\mathrm{e}$ & Dote et al. (1992) \\
\hline raw primary sludge waste active sludge & Crude fat & $1.9 \mathrm{e} 12.2$ & ether solvent & Suzuki et al. (1988) \\
\hline Secondary SS & Lipid & 8.01 & & Wang et al. (2018) \\
\hline Dewatered SS & Lipid & 5.0 & Soxhlet extraction (Diethyl ether) & Inoue et al. (1996) \\
\hline Liquidized SS & Lipid & 10.4 & & \\
\hline Digested sludge & $\begin{array}{l}\text { Crude- } \\
\text { lipid }\end{array}$ & $<1$ & Ether solvent & Vardon et al. (2011) \\
\hline Dewatered sludge Primary SS Secondary SS & Lipid & $\begin{array}{l}2.5 \text { e } 10.32 .2 \text { e } 7.53 .0 \\
\text { e } 7.5\end{array}$ & $\begin{array}{l}\text { Soxhlet extraction (hexane-ethanol) Acid hydrolysis Water bath } \\
\text { shaking }\end{array}$ & Zhu et al. (2014) \\
\hline Blended sludge & Lipid & $7.7 e 26.2$ & Soxhlet extraction (hexane) Liquid-liquid Extraction (hexane) & $\begin{array}{l}\text { Olkiewicz et al. } \\
\text { (2014) }\end{array}$ \\
\hline Raw sewage sludge & Lipid & 1217 e 18 & Soxhlet extraction (chloroform) Boiling extraction (chloroform) & $\begin{array}{l}\text { Boocock et al. } \\
\text { (1992) }\end{array}$ \\
\hline
\end{tabular}

-: Not mentioned.

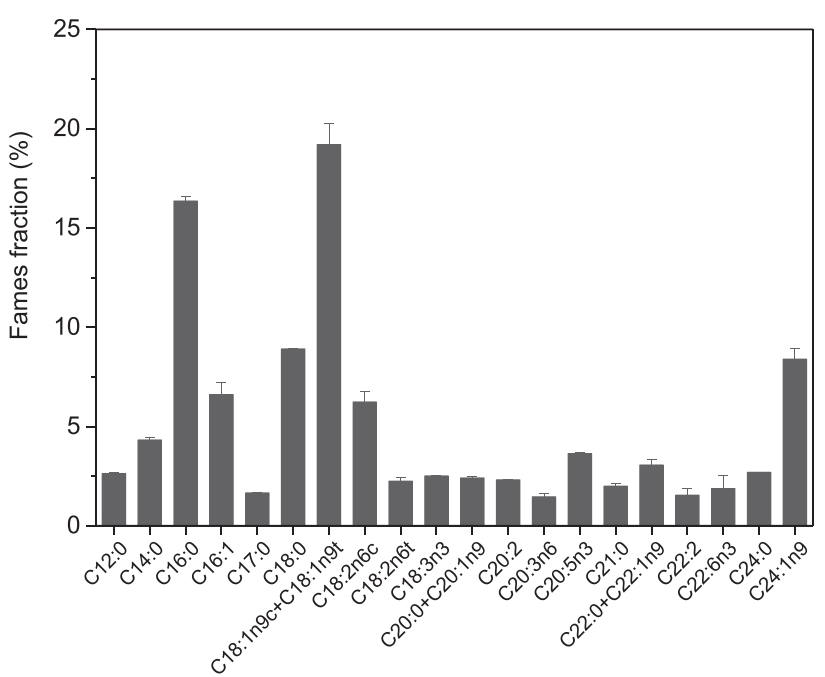

Fig. 1. FAMEs analysis of biodiesel obtained from the in-situ transesterification of SS.

residue yields at the temperatures used. The AQ forms the domi nant part of all the products, between 36.6 and $50.6 \mathrm{wt} \%$ in all cases, and slightly increased with reaction temperature.

\subsubsection{Carbon and nitrogen balance}

Table 3 shows the elemental balance/distribution in different phases, namely, carbon distribution (CD) and nitrogen distribution (ND), estimated using Eq. (3). For both SS and LESS, the carbon content in the SR significantly decreases from 64.1 to $29.1 \%$ and 58.2 to $38.5 \%$ with a temperature increase from 250 to $350{ }^{\circ} \mathrm{C}$, respec tively. In the bio crude phase, the $\mathrm{CD}$ correspondingly increases from 13.5 to $34.0 \%$ and from 12.5 to $27.6 \%$, respectively. The CD of the AQ seems stable, only showing a slight trend of decreasing with the reaction temperature. When considering the gas formed, while

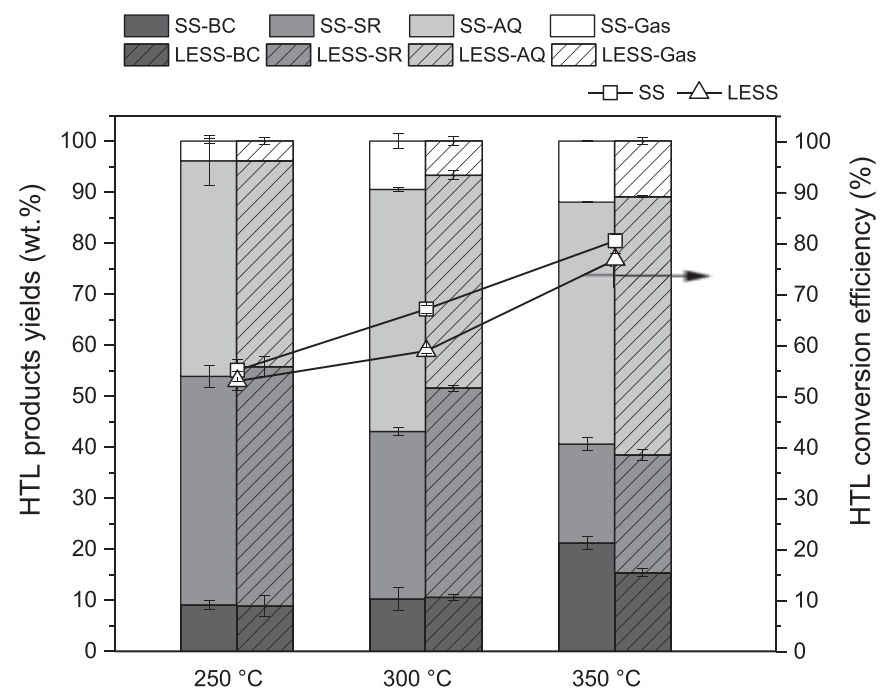

Fig. 2. Comparison between HTL of SS and LESS at different temperatures, the yield of the aqueous phase $(\mathrm{AQ})$ was determined as the difference between unity and the sum of the yields of bio-crude (BC), solid residue (SR), and bio-gas (Gas) fractions.

the yields are low ( $<12 \mathrm{wt} \%)$, the $\mathrm{CD}$ shows a rise by a factor of around 4 from 250 to $350{ }^{\circ} \mathrm{C}$.

Nitrogen has also been investigated as another important element with regard to the high protein content in both SS and LESS. In contrast to what was discussed for the case of carbon, nearly half the amount of nitrogen is recovered in the aqueous phase under all conditions. Due to this high nitrogen content, the aqueous phase has been considered as a promising medium to cultivate algae, with some success (Biller et al., 2012; Jena et al., 2011). With increasing temperature, the ND in the SR of SS and LESS is significantly reduced from 37.5 to $21.1 \%$ and 35.7 to $22.1 \%$, respectively. For the case of bio crude, increasing reaction 
Table 3

Carbon/Nitrogen distribution (CD/ND, wt.\%) of various products.

\begin{tabular}{|c|c|c|c|c|c|c|c|c|c|}
\hline \multirow[t]{2}{*}{ Samples } & \multicolumn{2}{|c|}{ Bio-crude } & \multicolumn{2}{|l|}{ Solid } & \multicolumn{2}{|c|}{$\begin{array}{l}\text { Aqueous } \\
\text { phase }\end{array}$} & \multirow{2}{*}{$\begin{array}{l}\text { Gas } \\
\overline{\mathrm{CD}}\end{array}$} & \multicolumn{2}{|c|}{ Recovery } \\
\hline & $\mathrm{CD}$ & ND & $\mathrm{CD}$ & ND & $C D$ & ND & & $\mathrm{CD}$ & ND \\
\hline $\mathrm{SS}-250^{\circ} \mathrm{C}$ & 13.5 & 10.3 & 64.1 & 45.5 & 19.6 & 48.8 & 2.5 & 99.8 & 104.6 \\
\hline $\mathrm{SS}-300^{\circ} \mathrm{C}$ & 17.1 & 12.1 & 53.6 & 38.0 & 15.6 & 47.1 & 6.2 & 92.6 & 97.2 \\
\hline $\mathrm{SS}-350^{\circ} \mathrm{C}$ & 34.0 & 20.8 & 29.1 & 25.6 & 14.8 & 42.2 & 8.2 & 86.2 & 88.7 \\
\hline LESS- $250^{\circ} \mathrm{C}$ & 12.5 & 11.0 & 54.6 & 40.2 & 21.3 & 42.2 & 2.2 & 90.7 & 93.4 \\
\hline LESS-300 ${ }^{\circ} \mathrm{C}$ & 17.3 & 11.5 & 49.2 & 35.9 & 15.6 & 45.2 & 4.6 & 86.7 & 92.6 \\
\hline LESS-350 ${ }^{\circ} \mathrm{C}$ & 27.6 & 16.7 & 38.5 & 31.3 & 14.0 & 44.6 & 9.4 & 89.6 & 92.5 \\
\hline
\end{tabular}

temperatures seem to lead to increased incorporation of nitrogen, as ND increases from 10.3 to $20.8 \%$ as the temperature rises from 250 to $350{ }^{\circ} \mathrm{C}$, affecting the usability of this phase.

HTL resulted in a considerable proportion of dissolved organic carbon and a major proportion of $\mathrm{N}$ in its aqueous phase in every case. Total organic carbon (TOC) analysis was applied to determine water soluble organic products, as shown in Fig. 3 (a). After HTL of SS and of LESS, TOC contents significantly decreased as the tem perature increased from 15,500 to $9000 \mathrm{mg} / \mathrm{L}$ and 14,900 to $6700 \mathrm{mg} / \mathrm{L}$, respectively. While at $250{ }^{\circ} \mathrm{C}$, the TOC in the aqueous phase from SS and LESS are similar, at higher temperatures, the TOC observed for the aqueous phase from LESS were lower than that from SS.

Regarding ammonium $\left(\mathrm{NH}_{4}^{+}\right)$, seen in Fig. 3 (b), the opposite trend was observed. After HTL of SS and LESS, $\mathrm{NH}_{4}^{+}$concentrations steadily increased with the temperature from 4000 to $6000 \mathrm{mg} / \mathrm{L}$ and $3000 \mathrm{e} 5000 \mathrm{mg} / \mathrm{L}$, respectively. In addition, the $\mathrm{NH}_{4}^{+}$content present in the AQ phase after HTL of SS was higher than that of LESS under the same conditions.

\subsubsection{Energy content of the products}

Table 4 summarizes element ratios and HHV for all bio crude and solid products. Further detailed elemental analyses are shown in Table S1. The extracted lipids exhibit HHV very similar to that of FAME (39.29 vs $39.5 \mathrm{MJ} \mathrm{kg}^{-1}$ ) (Pastore et al., 2013).

When comparing the raw SS and LESS, the bio crude obtai nedfrom $\mathrm{HTL}$ shows a lowering in the $\mathrm{H} / \mathrm{C}$ and $\mathrm{O} / \mathrm{C}$ ratios and higher HHV. The effect of temperature is most noticeable when comparing the results at $250{ }^{\circ} \mathrm{C}$ and $300{ }^{\circ} \mathrm{C}$, but the change between $300{ }^{\circ} \mathrm{C}$
Table 4

Elemental composition (atomic ratio), higher heating value (MJ\$kg ${ }^{1}$ ) of bio-crude and solid residue.

\begin{tabular}{|c|c|c|c|c|c|c|c|c|}
\hline \multirow[t]{2}{*}{ HTL } & \multicolumn{4}{|c|}{ Bio-crude } & \multicolumn{4}{|c|}{ Solid residue } \\
\hline & $\mathrm{H} / \mathrm{C}$ & $\mathrm{O} / \mathrm{C}$ & $\mathrm{N} / \mathrm{C}$ & HHV & $\mathrm{H} / \mathrm{C}$ & $\mathrm{O} / \mathrm{C}$ & $\mathrm{N} / \mathrm{C}$ & HHV \\
\hline Raw SS & & & & & 0.77 & 2.14 & 0.12 & 10.54 \\
\hline LESS & & & & & 0.70 & 2.07 & 0.13 & 10.03 \\
\hline Extracted lipids & 1.86 & 0.11 & 0.01 & 39.29 & & & & \\
\hline SS- $250^{\circ} \mathrm{C}$ & 0.18 & 1.62 & 0.09 & 32.29 & 0.38 & 1.56 & 0.09 & 10.02 \\
\hline SS $-300^{\circ} \mathrm{C}$ & 0.13 & 1.57 & 0.09 & 34.60 & 0.16 & 1.41 & 0.09 & 10.35 \\
\hline $\mathrm{SS}-350^{\circ} \mathrm{C}$ & 0.09 & 1.57 & 0.07 & 37.26 & 0.22 & 1.39 & 0.11 & 6.40 \\
\hline LESS- $250{ }^{\circ} \mathrm{C}$ & 0.24 & 1.56 & 0.12 & 28.85 & 0.48 & 1.52 & 0.10 & 8.29 \\
\hline LESS $-300^{\circ} \mathrm{C}$ & 0.11 & 1.45 & 0.09 & 34.76 & 0.49 & 1.31 & 0.10 & 7.11 \\
\hline LESS-350 ${ }^{\circ} \mathrm{C}$ & 0.12 & 1.45 & 0.08 & 34.91 & 0.27 & 1.33 & 0.11 & 6.82 \\
\hline
\end{tabular}

and $350^{\circ} \mathrm{C}$ is subtle and may lay within experimental uncertainty; this trend can be observed for experiments using both SS and LESS. Regarding the solid residue, HTL treatment led to lower $\mathrm{H} / \mathrm{C}$ and $\mathrm{O} /$ $\mathrm{C}$ ratios when compared to the feedstocks. The effect of tempera ture seems to be similar to that found for bio crude. All heating values ranged from 28 to $40 \mathrm{MJ} \mathrm{kg}^{-1}$, close to those reported for bio crude produced from sewage sludge (35e $40 \mathrm{MJ} \mathrm{kg}^{-1}$ ) (Qian et al., 2017) and paper sludge (35e $37 \mathrm{MJ} \mathrm{kg}^{-1}$ ) (Xu and Lancaster, 2008), but lower than that of petroleum crude oil (43 $\mathrm{MJ} \mathrm{kg}^{-1}$ ) (Speight, 2015). Low N/C ratios in the bio crude and high values in the solid residue confirm the results presented in Table 3.

\subsubsection{Bio crude composition}

Fig. 4 shows the groups of chemicals in the bio crudes obtained. The identification of organic compounds was achieved by comparing the spectra of sample components (limited to the top 50 compounds based on the peak normalized volume) with those in the electronic library of NIST. The organic components were analyzed using the area normalization method (Li et al., 2014). Detailed categories of constituents can be seen in Table S2 in the Supporting Information. The identified components account for more than $56 \%$ and $64 \%$ of the total species in the bio crude derived from SS and LESS, respectively. The major detected compounds are $\mathrm{N}$ containing heterocycles such as pyrazines, pyrrolidinones, and indoles, similar species have been described in a previous report (Zhai et al., 2014). These fractions slightly increase with reaction temperature in the case of HTL of SS. A decrease is observed from
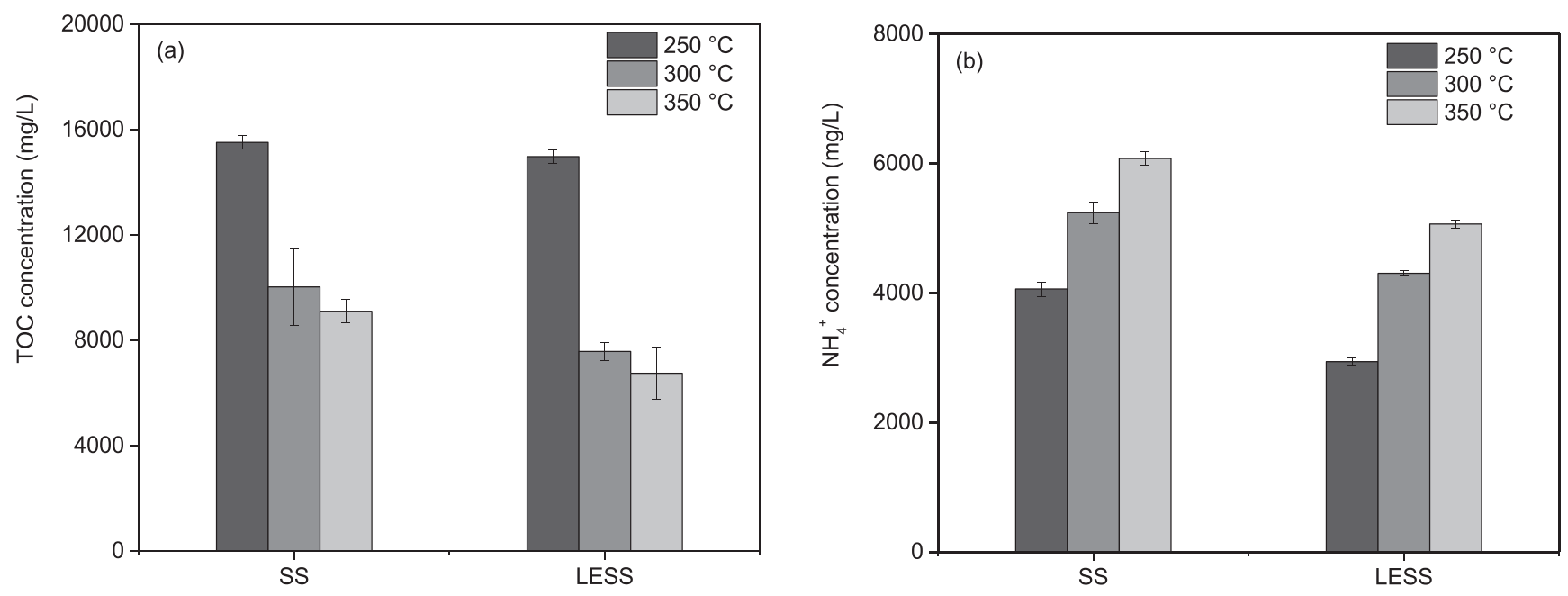

Fig. 3. Total organic carbon concentration (a) and ammonium concentration (b) in the aqueous phase from HTL of SS and LESS. 
HTL of LESS. O containing compounds form the second largest constituent of bio crude, mainly composed of phenolic compounds. It is observed that $O$ containing compounds in the bio crude from HTL of SS greatly decrease with increasing temperature, whereas, conversely, a higher amount of $\mathrm{O}$ containing compounds are formed in the case of HTL of LESS. The yield of hydrocarbons seems to be very influenced by the temperature (an increase from 1.5 to $20.1 \%$ ) for the case of SS, but an almost absence of these compounds in bio crude produced from LESS, due to negligible lipid content.

Regarding amines and amides, the lowest fractions are pro duced at $250{ }^{\circ} \mathrm{C}$ which may be a temperature too low to promote this type of reaction. Bio crude from LESS shows a higher value of said components, mostly including piperidines and acetamides. While, around $1.5 \%$ hexadecanamide could be found in bio crude stemming from $\mathrm{HTL}$ of SS at $300{ }^{\circ} \mathrm{C}$, indicating reactions between lipid and protein contents.

TGA analysis was applied to study the three stages of weight loss and its relationship to the results of GC MS analyses of the composition of the bio crude. The TGA curves of the 6 kinds of bio crude from HTL of SS and LESS are shown in Fig. S1 in the Sup porting Information. All HTL bio crudes show the same TGA curve progression, with a similar decomposition process. However, the derivative thermogravimetry (DTG) plot seems to be quite different. The DTG curves of bio crude from HTL of SS at 300 and $350^{\circ} \mathrm{C}$ show weight loss at $100^{\circ} \mathrm{C}$, indicating the presence of water. A relatively significant weight loss takes place between $180^{\circ} \mathrm{C}$ and $380^{\circ} \mathrm{C}$ with a peak at $290^{\circ} \mathrm{C}$. Regarding the HTL of LESS, a relatively significant weight loss occurs between $150{ }^{\circ} \mathrm{C}$ and $330^{\circ} \mathrm{C}$ with no specific peak. Another significant decomposition process is trig gered at around $430{ }^{\circ} \mathrm{C}$.

Table 5 further provides boiling point distributions which were calculated based on the weight loss during TGA measurement. Small differences in boiling point distribution trends are observed for HTL bio oils derived from SS and LESS. The most significant fractions correspond to compounds of volatilities similar to those of kerosene or diesel oil $\left(200{ }^{\circ} \mathrm{C}-400{ }^{\circ} \mathrm{C}\right)$, in agreement with results found by Liu et al. (2018). LESS bio crude contains more fractions in the gasoline range $\left(110-200{ }^{\circ} \mathrm{C}\right)$ and less in the heavy diesel $\left(300-400{ }^{\circ} \mathrm{C}\right)$ when compared to SS bio crude. The amount of distilled fractions between $200^{\circ} \mathrm{C}$ and $550{ }^{\circ} \mathrm{C}$, which can generally be used in petroleum refineries (Huang et al., 2016), accounted for around 71 to $74.1 \mathrm{wt} \%$ in bio crude from HTL of SS, and 67.2 to 70.9 wt\% in bio crude from HTL of LESS. Accordingly, it is worth noting that the heavy crude fraction $\left(>550{ }^{\circ} \mathrm{C}\right)$ in all bio crude is larger than $25.9 \mathrm{wt} \%$, the value reported from Liu et al. (2018), limiting the chances of direct refinery integration and requiring costly upgrading. More residues at higher boiling points $\left(>800^{\circ} \mathrm{C}\right)$ were obtained in the crude derived from HTL of LESS.

\section{Discussion}

\subsection{Possible reaction pathways for HTL of LESS}

Fig. 2 shows that the conversion of SS and LESS via HTL is comparable, suggesting that the residue after lipid extraction can be considered a suitable feedstock for the HTL process. For both cases, increasing temperature leads to increased conversion, along with a decrease of organic content in the solid residue. A lower amount of solid residue overall is found when using raw SS, indi cating that the lipids in the SS converted into water soluble com pounds, such as organic acids, a fact supported by the comparatively higher TOC concentration observed in the aqueous phase produced from SS (Fig. 3 (a)).

For lower temperatures $\left(250{ }^{\circ} \mathrm{C}\right)$, bio crude seems to be most likely produced by reactions between carbohydrates and proteins, such as Maillard reactions. In the case of LESS, the higher protein content may compensate for the absence of lipids in the feedstock. It is confirmed that Maillard reactions play a significant role in bio crude production, which is supported by the $\mathrm{N}$ containing het erocycles detected by GC MS (Fan et al., 2018; Zhang et al., 2016). However, when the temperature increases to $350{ }^{\circ} \mathrm{C}$, a larger amount of bio crude is produced from HTL of SS. This can be explained as follows: In one way, polar or water soluble fatty acids in the aqueous phase further convert or condense into crude like products. Fatty acids could undergo decarboxylation to produce alkenes or alkanes (Watanabe et al., 2006), indicated by the significantly higher amounts of hydrocarbons found in the crude phase, as shown in Fig. 4. In another way, these fatty acids get converted into bio crude constituents by cross linking reactions, like amide formation with proteins.

However, a fact to be taken into consideration is the limited solubility of lipids in DCM, which hinders their recovery and in fluences the estimated values of conversion. This may explain the similar yields of bio crude reported for SS and LESS at $250{ }^{\circ} \mathrm{C}$ (Fig. 2). It has been reported that soap formation can happen at low temperatures in the base reaction medium, which hinders product separation during the extraction of lipids from sewage (Mondala et al., 2009). When the temperature increases to $350{ }^{\circ} \mathrm{C}$, more bio crude from HTL of SS is found, which could partly be from DCM extracted lipids.

\subsubsection{HTL of palmitic acid}

HTL of palmitic acid (PA) at three different temperatures was conducted to support the above made hypotheses. PA was selected as model fatty acid as it has been widely confirmed as the major fatty acid in sewage sludge (Olkiewicz et al., 2012, 2014; Tang et al., 2019; Zhu et al., 2014), also identified from FAME as shown in Fig. 1.

Table 5

Boiling point distribution of bio-crude from HTL of SS and LESS.

\begin{tabular}{|c|c|c|c|c|c|c|c|}
\hline \multirow[t]{3}{*}{ Distillation Range $\left({ }^{\circ} \mathrm{C}\right)$} & \multirow[t]{3}{*}{ typical application ${ }^{\mathrm{a}}$} & \multicolumn{6}{|c|}{ Distribution (wt.\%) in Bio-crude } \\
\hline & & \multicolumn{3}{|l|}{ SS } & \multicolumn{3}{|l|}{ LESS } \\
\hline & & $250^{\circ} \mathrm{C}$ & $300{ }^{\circ} \mathrm{C}$ & $350^{\circ} \mathrm{C}$ & $250^{\circ} \mathrm{C}$ & $300^{\circ} \mathrm{C}$ & $350^{\circ} \mathrm{C}$ \\
\hline 20110 & Bottle gas & 3.3 & 2.6 & 2.8 & 2.3 & 3.8 & 1.6 \\
\hline 110200 & Gasoline & 12.7 & 11.8 & 13 & 14.7 & 19.7 & 14.7 \\
\hline 200300 & Jet fuel/Light diesel & 24.9 & 22.9 & 23.8 & 23.2 & 21.3 & 24.0 \\
\hline 300400 & Heavy diesel & 22 & 20.4 & 14.4 & 13.2 & 12.3 & 12.6 \\
\hline 400550 & Vacuum Gas Oil & 11.2 & 15.6 & 17 & 15.2 & 13.8 & 14.3 \\
\hline$<550$ & & 74.1 & 73.3 & 71 & 68.5 & 70.9 & 67.2 \\
\hline 550700 & Heavy Fuel Oil & 3.9 & 2.8 & 5.1 & 3.7 & 6.9 & 4 \\
\hline 700800 & Asphalt & 1.7 & 1.3 & 3.1 & 2.4 & 5.2 & 2.0 \\
\hline$>800$ & Residue & 20.3 & 22.6 & 20.8 & 25.4 & 17 & 26.8 \\
\hline
\end{tabular}

${ }^{\mathrm{a}}$ Handbook of Petroleum Product Analysis (Speight, 2015). 


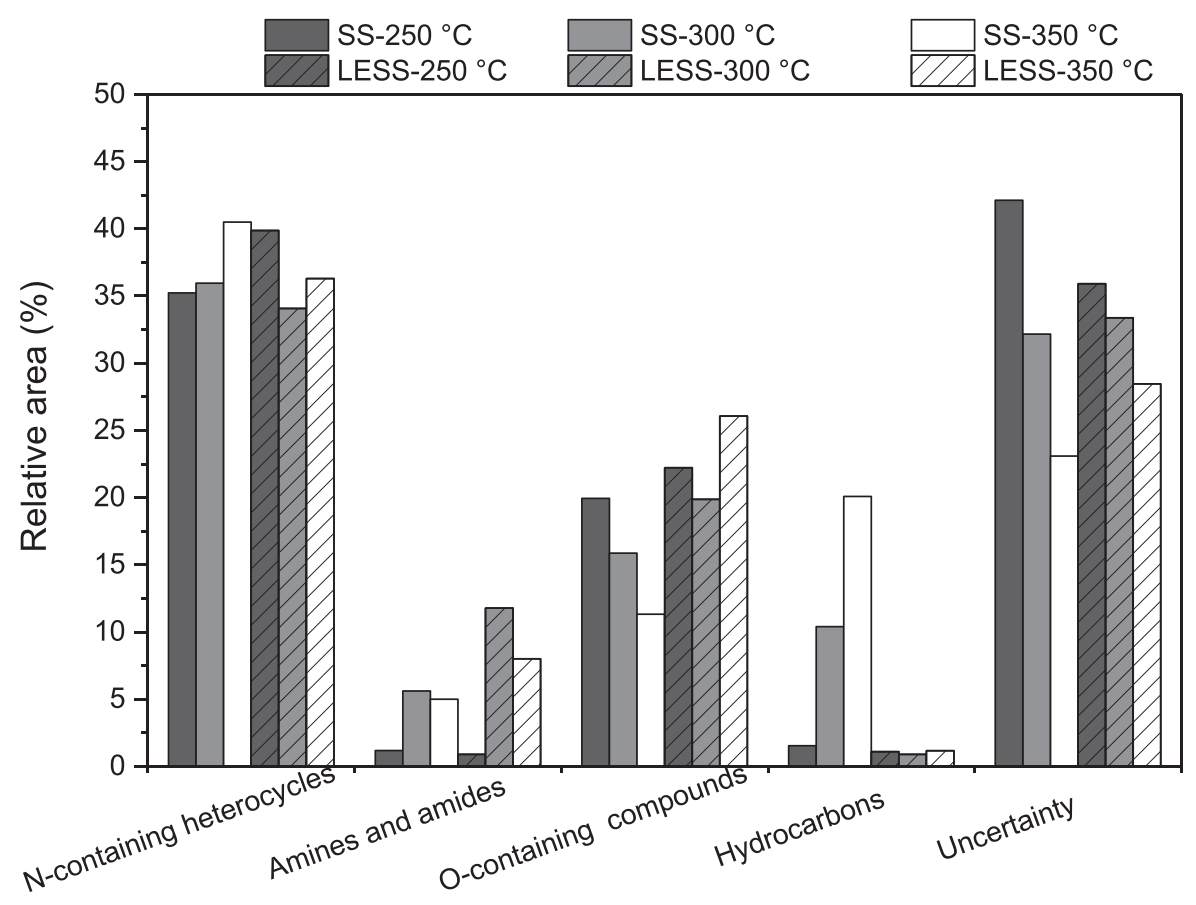

Fig. 4. Chemical groups represented inbio-crude obtained from HTL of SS and LESS under different temperatures.

Despite the increase in temperature, the carbon distribution to the solid residue was kept practically constant when increasing tem perature from 250 to $300^{\circ} \mathrm{C}$. Analysis of the solid residue from HTL of PA (Table S3 in the Supporting Information) showed that this fraction is essentially indistinguishable from palmitic acid. This fact stems from low solubility of this lipid in DCM, affecting the esti mation of the conversion, which presents low values when compared to HTL of SS or LESS $\left(6.4 \%\right.$ at $250{ }^{\circ} \mathrm{C}$, to $10.9 \%$ at $350{ }^{\circ} \mathrm{C}$, Fig. 5). Accordingly, the TOC concentration in the aqueous phase is low, increasing from 64 to $259 \mathrm{mg} / \mathrm{L}$, suggesting that PA is resistant to decomposition below $350{ }^{\circ} \mathrm{C}$. This is in agreement with the findings from HTL of LESS and SS, where lipids only slightly

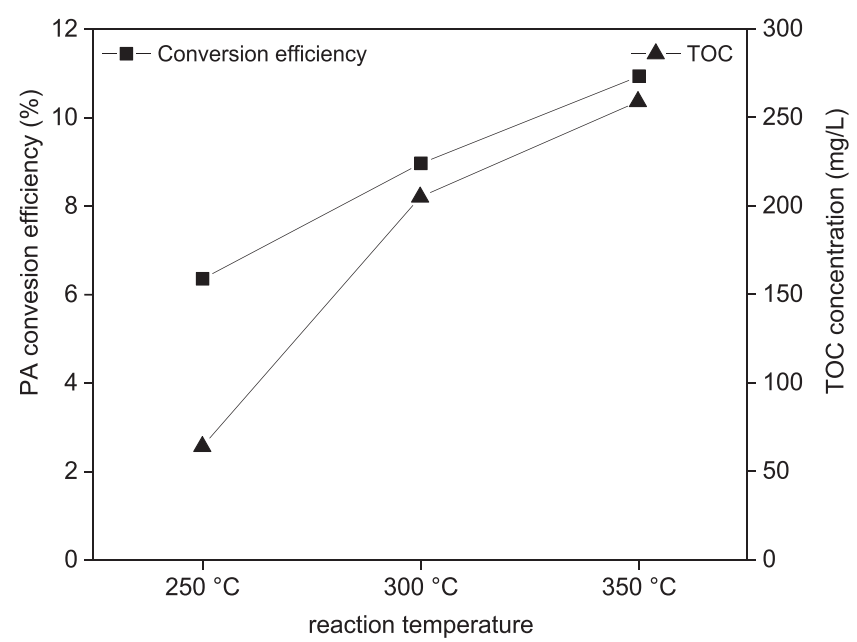

Fig. 5. Evolution of conversion and TOC concentration in the aqueous phase for HTL of $\mathrm{PA}$ (palmitic acid) at different temperatures. contribute to the bio crude at lower temperatures. The main portion of the unreacted PA remains solid and is collected as "solid residue", a part of the PA is extracted by a DCM solvent to form bio crude products. This outcome is likely due to the limited amount of DCM being unable to fully dissolve all of the fatty acids, suggesting the bio crude yield depends on the amount of solvent and the separation procedure. This observation is greatly consistent with the reports from Watson et al., 2019 and Qian et al. (2017), that the extraction solvent selection should be carefully considered and normalized for the reporting of hydrothermal liquefaction yields and energy efficiency values.

\subsection{Integration of lipid extraction and HTL of LESS}

Fig. 6 presents a block flow diagram of the processes considered in this work. The mass yields of the liquid fuels (bio crude and extracted lipid) obtained in the different process configurations of are shown in Table 6.

The combined yields represent the total yield of extracted lipids and bio crude produced from LESS. Accordingly, the HHV is calculated from that of both components. When looking at the evolution of the bio crude yield without considering lipid extrac tion, the jump in yield is significant between $300{ }^{\circ} \mathrm{C}$ and $350{ }^{\circ} \mathrm{C}$, while being negligible between $250^{\circ} \mathrm{C}$ and $300^{\circ} \mathrm{C}$. A similar, albeit more moderate effect can be found when performing HTL of LESS. The yield of extracted lipid exceeds the yield in bio crude at $250{ }^{\circ} \mathrm{C}$ and $300{ }^{\circ} \mathrm{C}$, leading to combined yields (HTL + extraction) which are more than double the value obtained using HTL alone. At $350{ }^{\circ} \mathrm{C}$, the high bio crude yields diminish the effect of this coupling. Moreover, the calculated HHV is higher than those of the bio crude from HTL of SS. It appears that the greater efficiency of value added fuel can be obtained from combining these two methods. Since lipids are commonly seen as biodiesel feedstock, which contains fewer heteroatoms in the target products, it is possible and efficient to extract lipids before conducting the HTL 


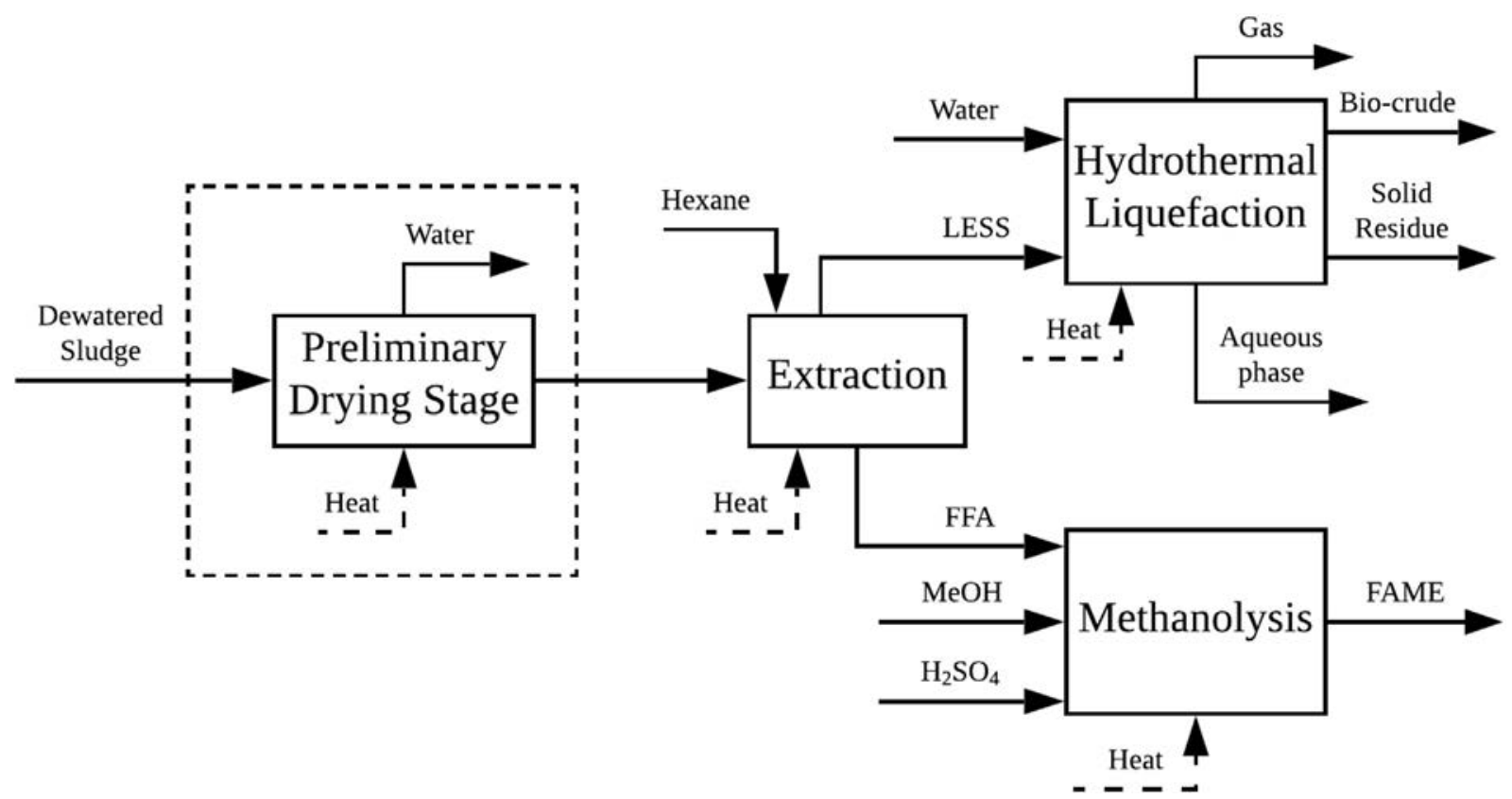

Fig. 6. Block flow diagram of combined lipid extraction, HTL and methanolysis for FAME production. The checkered box represents a part of the process that may be disregarded due to direct lipid extraction from wet sludge.

Table 6

Comparing the Mass yields of lipid extraction and HTL and their combination. Values in brackets correspond to the HHV of the product (MJ kg ${ }^{1}$ ).

\begin{tabular}{|c|c|c|c|c|}
\hline \multirow[t]{2}{*}{ Temperature $\left({ }^{\circ} \mathrm{C}\right)$} & \multirow[t]{2}{*}{ Extraction yield (wt.\%) } & \multicolumn{3}{|c|}{ Liquid fuel products yields (wt.\%) } \\
\hline & & Bio-crude of SS & Bio-crude of LESS & Combined Lipid extraction plus bio-crude \\
\hline 250 & $13.9(39.4)$ & $9.13(32.29)$ & $8.86(28.85)$ & $22.76(35.29)$ \\
\hline 300 & & $10.27(34.60)$ & $10.55(34.76)$ & $24.45(37.39)$ \\
\hline 350 & & $21.26(37.26)$ & 15.39 (34.91) & $29.29(37.04)$ \\
\hline
\end{tabular}

conversion in order to achieve a better energy valorization.

However, the higher nitrogen content in the bio crude from HTL of LESS has to be kept in mind, as it does not meet fuel standards. Post treatments like upgrading and distillation could be applied as effective, albeit costly, processes to reduce or remove nitrogen from bio crude (Elliott et al., 2013; Ramirez et al., 2015). For the latter case, lesser efforts must be taken to reduce the acidity of the dis tillates owing to the extraction of fatty acids.

Table 7 shows the heat requirements for the combined process. Drying is a substantial part of the energy demand, contributing to around half of the heat demand when employed. HTL and lipid extraction show very similar heat demands, while the energy de mand of methanolysis is seemingly negligible.

In Table 8, estimations of energy recovery (ER, Eq. (5)), energy consumption ratio (ECR, Eq. (6)) and energy demand (ED) per mass of produced bio crude/FAME are shown. The estimation has been carried out based on two cases, A and B, which employ different efficiencies for combustion and heat recovery, respectively. ECR is estimated for different scenarios, considering the production of only bio crude $\left(E C R_{B C}\right)$, both bio crude and bio char $\left(E C R_{B C}+S R\right)$, the

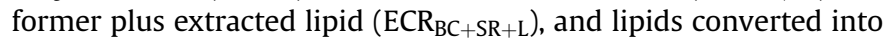
FAME $\left(E R_{B C+S R+F A M E}\right)$. While conventional lipid extraction re quires the drying of sludge (Dufreche et al., 2007; Pastore et al., 2013), recently the feasibility of performing extraction of non dried sludge (Olkiewicz et al., 2014; Pastore et al., 2013) has been shown, thus the estimations on energy efficiency considers the process with and without drying step.

Since the effect of temperature on the HHV of the formed phases can be neglected, the energy recovery is mostly determined by the product distribution, favoring higher temperatures for bio crude formation. SS shows lower energy recovery when compared to those found for LESS at the same temperature, due to the absence of the lipid phase, which features a high HHV. Also, ECR values are given in Table 8. Employing only HTL in case, an assuming

Table 7

Energy requirements (MJ $\mathrm{kg}^{1}$ ) for different steps of the integrated process (without considering heat recovery).

\begin{tabular}{|c|c|c|c|c|c|c|}
\hline & Combined process & HTL & Drying & Extraction & Methanolysis & Total \\
\hline \multirow[t]{3}{*}{ With drying } & LESS- $250^{\circ} \mathrm{C}$ & 45.1 & 112.8 & 61.0 & 2.2 & 221.1 \\
\hline & LESS $-300^{\circ} \mathrm{C}$ & 54.9 & & & & 230.9 \\
\hline & LESS- $350^{\circ} \mathrm{C}$ & 64.7 & & & & 240.7 \\
\hline \multirow[t]{3}{*}{ Without drying } & LESS- $250^{\circ} \mathrm{C}$ & 45.1 & & 61.0 & 2.2 & 108.3 \\
\hline & LESS $-300{ }^{\circ} \mathrm{C}$ & 54.9 & & & & 118.1 \\
\hline & LESS- $350^{\circ} \mathrm{C}$ & 64.7 & & & & 127.9 \\
\hline
\end{tabular}


Table 8

Estimation of the Energy Recovery (ER) and Energy Consumption Ratio (ECR), as well as the Energy Demand (ED) of HTL and combined processes. Value assuming a FAME yield of $8.5 \mathrm{wt} \%$ of the dry sludge.

\begin{tabular}{|c|c|c|c|c|c|c|c|c|c|c|c|c|c|c|}
\hline & \multirow[t]{2}{*}{ Process } & \multirow{2}{*}{$\begin{array}{l}\text { ER } \\
\frac{(\%)}{}\end{array}$} & \multicolumn{2}{|c|}{$\mathrm{ECR}_{\mathrm{BC}}$} & \multicolumn{2}{|c|}{$\mathrm{ECR}{ }_{\mathrm{BC}+\mathrm{SR}}$} & \multicolumn{2}{|c|}{$\mathrm{ECR}_{\mathrm{BC}+\mathrm{SR}+\mathrm{L}}$} & \multicolumn{2}{|c|}{$\begin{array}{l}\text { ECR } \\
\text { BC+SR+FAME }\end{array}$} & \multicolumn{2}{|c|}{$\begin{array}{l}\text { Energy demand } \\
\mathrm{MJ} /(\mathrm{kg} \mathrm{BC})\end{array}$} & \multicolumn{2}{|c|}{$\begin{array}{l}\text { Energy } \\
\text { demand } \mathrm{MJ} /(\mathrm{kg} \\
\text { FAME })\end{array}$} \\
\hline & & & A & B & A & B & A & B & A & B & A & B & A & B \\
\hline \multirow[t]{3}{*}{ Only HTL } & $\mathrm{SS}-250^{\circ} \mathrm{C}$ & 85.4 & 1.52 & 0.95 & 0.31 & 0.19 & & & & & 34.4 & 27.5 & & \\
\hline & $\mathrm{SS}-300^{\circ} \mathrm{C}$ & 82.1 & 1.54 & 0.96 & 0.78 & 0.48 & & & & & 37.2 & 29.7 & & \\
\hline & $\mathrm{SS}-350^{\circ} \mathrm{C}$ & 78.2 & 0.81 & 0.50 & 0.70 & 0.44 & & & & & 21.2 & 16.9 & & \\
\hline \multirow[t]{3}{*}{ With drying } & LESS $-250^{\circ} \mathrm{C}$ & 98.3 & 1.91 & 1.19 & 0.76 & 0.47 & 1.91 & 1.19 & 1.93 & 1.20 & 185.4 & 147.6 & 110.5 & 88.4 \\
\hline & LESS $-300^{\circ} \mathrm{C}$ & 92.3 & $1.69^{\mathrm{a}}$ & $1.05^{\mathrm{a}}$ & $0.94^{\mathrm{a}}$ & $0.59^{\mathrm{a}}$ & 2.02 & 1.26 & 2.03 & 1.26 & 169.7 & 135.1 & 115.4 & 92.4 \\
\hline & LESS- $350^{\circ} \mathrm{C}$ & 96.7 & $1.37^{\mathrm{a}}$ & $0.85^{\mathrm{a}}$ & $1.06^{\mathrm{a}}$ & $0.66^{\mathrm{a}}$ & 2.05 & 1.28 & 2.07 & 1.28 & 121.9 & 97.1 & 120.3 & 96.3 \\
\hline \multirow[t]{3}{*}{ Without drying } & LESS $-250^{\circ} \mathrm{C}$ & 98.3 & $1.91^{\mathrm{a}}$ & $1.19^{\mathrm{a}}$ & $0.76^{\mathrm{a}}$ & $0.47^{\mathrm{a}}$ & 0.93 & 0.58 & 0.94 & 0.59 & 88.9 & 70.4 & 54.1 & 43.3 \\
\hline & LESS-300 ${ }^{\circ} \mathrm{C}$ & 92.3 & $1.69^{\mathrm{a}}$ & $1.05^{\mathrm{a}}$ & $0.94^{\mathrm{a}}$ & $0.59^{a}$ & 1.02 & 0.64 & 1.04 & 0.65 & 85.2 & 67.5 & 59.0 & 47.2 \\
\hline & LESS- $350^{\circ} \mathrm{C}$ & 96.7 & $1.37^{\mathrm{a}}$ & $0.85^{\mathrm{a}}$ & $1.06^{\mathrm{a}}$ & $0.66^{\mathrm{a}}$ & 1.08 & 0.67 & 1.10 & 0.68 & 63.7 & 50.5 & 63.9 & 51.1 \\
\hline
\end{tabular}

a Only HTL o|f LESS is considered.

conservative efficiencies, the calculated ECR for SS is higher than 1 at temperatures below $350{ }^{\circ} \mathrm{C}$, suggesting that $\mathrm{HTL}$ is energeti cally inefficient, which aligns with the findings from $\mathrm{Xu}$ et al.(Xu and Lancaster, 2008). However, the energy efficiency can be improved with more favorable conditions, as shown for case B, and energy breakeven can always be achieved. Table 8 also shows that ECR obtained for SS is lower than that obtained for LESS at the same temperature, due to the energy demand for extraction and drying processes (Table 7). A similar trend was reported by Vardon et al. (2012), where ECR obtained from algae was lower than that from defatted algae. However, in their work, a favorable energy balance was achieved (ECR 0.44-0.55), probably owing to the high bio crude yields (36-45 wt\%) and the exclusion of energy consump tion for drying and lipid extraction.

The combined process (HTL + extraction) present higher ECRs and energy demands than the case where only HTL is considered, also explainable by the additional heat requirements for drying and extraction. The minimal effect of methanolysis, aided by the slightly higher HHV of FAME, leads to a negligible difference in ECR be tween the lipid case and the FAME case for all temperatures. The omission of the drying step leads to a halving of the energy demand of the process. The values of the energy demand for the process with drying reported in this work are lower than those obtained by Pastore et al. (2013) for the methanolysis of dewatered sludge (140-187 MJ $\cdot \mathrm{kg}^{-1}$ FAME). However, when disregarding drying, the process reaches values compared to the combined process pre sented by Pastore et al. (44-60 MJ $\cdot \mathrm{kg}^{-1}$ FAME) (Pastore et al., 2013). When including the energy demand for drying, this value increases greatly.

\section{Conclusion}

This work focuses on a novel proposal to maximize energy valorization of sewage sludge, by integrating lipid extraction and hydrothermal liquefaction of the lipid extracted sewage sludge residue. The extracted lipid can be employed for the production of biodiesel (FAME), while the remaining organics in the residual sewage sludge (lipid extracted, LESS) can be further converted into value added products via hydrothermal liquefaction. The combined approach improves the liquid bio fuel products (29.29 wt\%) compared with HTL of un extracted sludge (21.26 wt\%) at opti mized temperature. Possible key reactions during HTL have been proposed based on additional experiments with model substance. The majority of lipids in the sewage sludge cannot be converted into bio crude at lower temperatures. Maillard reactions signifi cantly contribute to the formation of bio crude components but show high nitrogen contents. Regarding the energetic efficiency of the process, energy recovery of around $98 \%$ could be achieved by the coupled process, which has a significant temperature de pendency. Analysis of the energy consumption ratio (ECR, 1.91-2.05) of the process disfavors the coupled process due to the energetic requirements of drying $\left(112.8 \mathrm{MJ} \mathrm{kg}^{-1}\right)$ and lipid extrac tion (61.0 MJ kg-1). However, the energetic efficiency can be improved if making use of state of the art technology.

\section{CRediT authorship contribution statement}

Y. Fan: designed and performed the experiments, and analyzed the data, calculated the energetic efficiency and wrote discussion, wrote the manuscript in consultation with M. Gong, U. Hornung and N. Dahmen. F.G. Fonseca: calculated the energetic efficiency and wrote discussion. A. Hoffmann: designed and performed the experiments, and analyzed the data. U. Hornung: supervised the project, and put efforts to revise the manuscript. N. Dahmen: su pervised the project, and put efforts to revise the manuscript, All authors discussed the results and commented on the manuscript..

\section{Declaration of competing interest}

The authors declare that they have no known competing financial interests or personal relationships that could have appeared to influence the work reported in this paper.

\section{Acknowledgements}

Armin Lautenbach, Birgit Rolli, Alexandra Bohm, Jessica Mayer, and Sonja Habicht are thanked gratefully for their skillful technical assistance. Thomas Tietz and Matthias Pagel are thanked for the mechanical support. Prof. Julie B. Zimmerman is greatly appreci ated for all valuable comments which help us to largely improve the quality of this manuscript. We would like to thank the valuable comments of previous reviewers, which contributed to the quality of the final work. One the authors (F.G. Fonseca) is a member of the BBW ForWerts Graduate Program. The authors gratefully acknowledge the financial support from the China Scholarship Council, the National Natural Science Foundation (52000056) of PR China, the Natural Science Foundation of Anhui Province (1808085QE142). 


\section{References}

Biller, P., Ross, A.B., Skill, S.C., Lea-Langton, A., Balasundaram, B., Hall, C., Riley, R., Llewellyn, C.A., 2012. Nutrient recycling of aqueous phase for microalgae cultivation from the hydrothermal liquefaction process. Algal Research 1, 7076.

Boocock, D.G.B., Konar, S.K., Leung, A., Ly, L.D., 1992. Fuels and chemicals from sewage sludge: 1 . The solvent extraction and composition of a lipid from a raw sewage sludge. Fuel 71, 12831289.

Cai, M., Liu, J., Wei, Y., 2004. Enhanced biohydrogen production from sewage sludge with alkaline pretreatment. Environ. Sci. Technol. 38, 31953202.

Chen, G.Y., Hu, M.T., Du, G.Y., Tian, S., He, Z.Y., Liu, B., Ma, W.C., 2020. Hydrothermal liquefaction of sewage sludge by microwave pretreatment. Energy Fuels 34, 11451152.

Chopra, J., Mahesh, D., Yerrayya, A., Vinu, R., Kumar, R., Sen, R., 2019. Performance enhancement of hydrothermal liquefaction for strategic and sustainable valorization of de-oiled yeast biomass into green bio-crude. J. Clean. Prod. 227, 292301.

Demirbas, A., 2009. Combustion efficiency impacts of biofuels. Energy Sources, Part A Recovery, Util. Environ. Eff. 31, 602609.

di Bitonto, L., Locaputo, V., D’Ambrosio, V., Pastore, C., 2020. Direct Lewis-Brønsted acid ethanolysis of sewage sludge for production of liquid fuels. Appl. Energy 259, 114163.

Dote, Y., Hayashi, T., Suzuki, A., Ogi, T., 1992. Analysis of oil derived from liquefaction of sewage sludge. Fuel 71, 10711073.

Dufreche, S., Hernandez, R., French, T., Sparks, D., Zappi, M., Alley, E., 2007. Extraction of lipids from municipal wastewater plant microorganisms for production of biodiesel. J. Am. Oil Chem. Soc. 84, 181187.

Elliott, D.C., Hart, T.R., Schmidt, A.J., Neuenschwander, G.G., Rotness, L.J., Olarte, M.V., Zacher, A.H., Albrecht, K.O., Hallen, R.T., Holladay, J.E., 2013. Process development for hydrothermal liquefaction of algae feedstocks in a continuousflow reactor. Algal Research 2, 445454.

Fan, Y., Hornung, U., Dahmen, N., Kruse, A., 2018. Hydrothermal liquefaction of protein-containing biomass: study of model compounds for Maillard reactions. Biomass Conversion and Biorefinery 8, 909923.

Fox, J.T., Zook, A.N., Freiss, J., Appel, B., Appel, J., Ozsuer, C., Sarac, M., 2019. Thermal conversion of blended food production waste and municipal sewage sludge to recoverable products. J. Clean. Prod. 220, 5764.

Frank, E.D., Elgowainy, A., Han, J., Wang, Z., 2012. Life cycle comparison of hydrothermal liquefaction and lipid extraction pathways to renewable diesel from algae. Mitig. Adapt. Strategies Glob. Change 18, 137158.

Gao, J., Wang, Y., Yan, Y., Li, Z., Chen, M., 2020. Protein extraction from excess sludge by alkali-thermal hydrolysis. Environ. Sci. Pollut. Res. Int. 27, 86288637.

Gherghel, A., Teodosiu, C., De Gisi, S., 2019. A review on wastewater sludge valorisation and its challenges in the context of circular economy. J. Clean. Prod. 228, 244263.

Huang, Y., Chen, Y., Xie, J., Liu, H., Yin, X., Wu, C., 2016. Bio-oil production from hydrothermal liquefaction of high-protein high-ash microalgae including wild Cyanobacteria sp. and cultivated Bacillariophyta sp. Fuel 183, 919.

Huo, H., Wang, M., Bloyd, C., Putsche, V., 2009. Life-Cycle assessment of energy use and greenhouse gas emissions of soybean-derived biodiesel and renewable fuels. Environ. Sci. Technol. 43, 750756.

Inoue, S., Sawayama, S., Ogi, T., Yokoyama, S.-y., 1996. Organic composition of liquidized sewage sludge. Biomass Bioenergy 10, 3740.

Jena, U., Vaidyanathan, N., Chinnasamy, S., Das, K.C., 2011. Evaluation of microalgae cultivation using recovered aqueous co-product from thermochemical liquefaction of algal biomass. Bioresour. Technol. 102, 33803387.

Jimenez, J., Vedrenne, F., Denis, C., Mottet, A., Déléris, S., Steyer, J.-P., Cacho Rivero, J.A., 2013. A statistical comparison of protein and carbohydrate characterisation methodology applied on sewage sludge samples. Water Res. 47, 17511762.

Kapusta, K., 2018. Effect of ultrasound pretreatment of municipal sewage sludge on characteristics of bio-oil from hydrothermal liquefaction process. Waste Manag. 78, 183-190-2018 v.2078.

Kech, C., Galloy, A., Frippiat, C., Piel, A., Garot, D., 2018. Optimization of direct liquidliquid extraction of lipids from wet urban sewage sludge for biodiesel production. Fuel 212, 132139.

Kruse, A., Dahmen, N., 2018. Hydrothermal biomass conversion: quo vadis? J. Supercrit. Fluids 134, 114123.

Kwon, E.E., Kim, S., Jeon, Y.J., Yi, H., 2012. Biodiesel production from sewage sludge: new paradigm for mining energy from municipal hazardous material. Environ. Sci. Technol. 46, 1022210228.

Li, H., Liu, Z., Zhang, Y., Li, B., Lu, H., Duan, N., Liu, M., Zhu, Z., Si, B., 2014. Conversion efficiency and oil quality of low-lipid high-protein and high-lipid low-protein microalgae via hydrothermal liquefaction. Bioresour. Technol. 154, 322329.

Liu, R., Tian, W., Kong, S., Meng, Y., Wang, H., Zhang, J., 2018. Effects of inorganic and organic acid pretreatments on the hydrothermal liquefaction of municipal secondary sludge. Energy Convers. Manag. 174, 661667.

Minowa, T., Kondo, T., Sudirjo, S.T., 1998. Thermochemical liquefaction of Indonesian biomass residues. Biomass Bioenergy 14, 517524.

Mondala, A., Liang, K., Toghiani, H., Hernandez, R., French, T., 2009. Biodiesel production by in situ transesterification of municipal primary and secondary sludges. Bioresour. Technol. 100, 12031210.

Olkiewicz, M., Caporgno, M.P., Fortuny, A., Stüber, F., Fabregat, A., Font, J., Bengoa, C., 2014. Direct liquid liquid extraction of lipid from municipal sewage sludge for biodiesel production. Fuel Process. Technol. 128, 331338.

Olkiewicz, M., Fortuny, A., Stüber, F., Fabregat, A., Font, J., Bengoa, C., 2012. Evaluation of different sludges from WWTP as a potential source for biodiesel production. Procedia Engineering 42, 634643.

Pastore, C., Lopez, A., Lotito, V., Mascolo, G., 2013. Biodiesel from dewatered wastewater sludge: a two-step process for a more advantageous production. Chemosphere 92, $667 \quad 673$.

Peccia, J., Westerhoff, P., 2015. We should expect more out of our sewage sludge. Environ. Sci. Technol. 49, 82718276.

Pokoo-Aikins, G., Heath, A., Mentzer, R.A., Sam Mannan, M., Rogers, W.J., ElHalwagi, M.M., 2010. A multi-criteria approach to screening alternatives for converting sewage sludge to biodiesel. J. Loss Prev. Process. Ind. 23, 412420.

Posmanik, R., Cantero, D.A., Malkani, A, Sills, D.L, Tester, J.W, 2017, Biomass conversion to bio-oil using sub-critical water: study of model compounds for food processing waste. J. Supercrit. Fluids 119, 2635.

Qian, L., Wang, S., Savage, P.E., 2017. Hydrothermal liquefaction of sewage sludge under isothermal and fast conditions. Bioresour. Technol. 232, 2734.

Ramirez, J., Brown, R., Rainey, T., 2015. A review of hydrothermal liquefaction biocrude properties and prospects for upgrading to transportation fuels. Energies 8,67656794

Rao, U., Posmanik, R., Hatch, L.E., Tester, J.W., Walker, S.L., Barsanti, K.C., Jassby, D., 2018. Coupling hydrothermal liquefaction and membrane distillation to treat anaerobic digestate from food and dairy farm waste. Bioresour. Technol. 267, 408415.

Sawayama, S., Minowa, T., Yokoyama, S.Y., 1999. Possibility of renewable energy production and $\mathrm{CO} 2$ mitigation by thermochemical liquefaction of microalgae. Biomass Bioenergy 17, 3339.

Shahi, T., Beheshti, B., Zenouzi, A., Almasi, M., 2020. Bio-oil production from residual biomass of microalgae after lipid extraction: the case of Dunaliella Sp. Biocatalysis and Agricultural Biotechnology 23, 101494.

Siddiquee, M.N., Rohani, S., 2011. Lipid extraction and biodiesel production from municipal sewage sludges: a review. Renew. Sustain. Energy Rev. 15, 10671072.

Speight, J.G., 2015. Handbook of Petroleum Product Analysis. John Wiley \& Sons.

Supaporn, P., Yeom, S.H., 2016. Optimization of a two-step biodiesel production process comprised of lipid extraction from blended sewage sludge and subsequent lipid transesterification. Biotechnol. Bioproc. Eng. 21, 551560.

Suzuki, A., Nakamura, T., Yokoyama, S.-Y., Ogi, T., Koguchi, K., 1988. Conversion OF sewage sludge to heavy oil BY direct thermochemical liquefaction. J. Chem. Eng. Jpn. 21, 288293.

Syed-Hassan, S.S.A., Wang, Y., Hu, S., Su, S., Xiang, J., 2017. Thermochemical processing of sewage sludge to energy and fuel: fundamentals, challenges and considerations. Renew. Sustain. Energy Rev. 80, 888913.

Tang, S., Shi, Z., Tang, X., Yang, X., 2019. Hydrotreatment of biocrudes derived from hydrothermal liquefaction and lipid extraction of the high-lipid Scenedesmus. Green Chem. 21, 34133423.

Vardon, D.R., Sharma, B.K., Blazina, G.V., Rajagopalan, K., Strathmann, T.J., 2012. Thermochemical conversion of raw and defatted algal biomass via hydrothermal liquefaction and slow pyrolysis. Bioresour. Technol. 109, 178187.

Vardon, D.R., Sharma, B.K., Scott, J., Yu, G., Wang, Z., Schideman, L., Zhang, Y., Strathmann, T.J., 2011. Chemical properties of biocrude oil from the hydrothermal liquefaction of Spirulina algae, swine manure, and digested anaerobic sludge. Bioresour. Technol. 102, 82958303.

Wang, W., Yu, Q., Meng, H., Han, W., Li, J., Zhang, J., 2018. Catalytic liquefaction of municipal sewage sludge over transition metal catalysts in ethanol-water cosolvent. Bioresour. Technol. 249, 361367.

Watanabe, M., Iida, T., Inomata, H., 2006. Decomposition of a long chain saturated fatty acid with some additives in hot compressed water. Energy Convers. Manag. 47, 33443350.

Watson, J., Lu, J., de Souza, R., Si, B., Zhang, Y., Liu, Z., 2019. Effects of the extraction solvents in hydrothermal liquefaction processes: biocrude oil quality and energy conversion efficiency. Energy 167, 189197.

$\mathrm{Xu}, \mathrm{C}$., Lancaster, J., 2008. Conversion of secondary pulp/paper sludge powder to liquid oil products for energy recovery by direct liquefaction in hot-compressed water. Water Res. 42, 15711582

Yang, J., He, Q., Yang, L., 2019. A review on hydrothermal co-liquefaction of biomass. Appl. Energy 250, 926945.

Zhai, Y., Chen, H., Xu, B., Xiang, B., Chen, Z., Li, C., Zeng, G., 2014. Influence of sewage sludge-based activated carbon and temperature on the liquefaction of sewage sludge: yield and composition of bio-oil, immobilization and risk assessment of heavy metals. Bioresour. Technol. 159, 7279.

Zhang, C., Tang, X., Sheng, L., Yang, X., 2016. Enhancing the performance of Cohydrothermal liquefaction for mixed algae strains by the Maillard reaction. Green Chem. 18, 25422553.

Zhu, F., Zhao, L., Jiang, H., Zhang, Z., Xiong, Y., Qi, J., Wang, J., 2014. Comparison of the lipid content and biodiesel production from municipal sludge using three extraction methods. Energy Fuels 28, 52775283. 
Karlsruher Institut für Technologie

\section{Repository KITopen}

Dies ist ein Postprint/begutachtetes Manuskript.

Empfohlene Zitierung:

Fan, Y.; Fonseca, F. G.; Gong, M.; Hoffmann, A.; Hornung, U.; Dahmen, N.

Energy valorization of integrating lipid extraction and hydrothermal liquefaction of lipidextracted sewage sludge.

2021. Journal of cleaner production, 285.

doi:10.5445/IR/1000126656

Zitierung der Originalveröffentlichung:

Fan, Y.; Fonseca, F. G.; Gong, M.; Hoffmann, A.; Hornung, U.; Dahmen, N.

Energy valorization of integrating lipid extraction and hydrothermal liquefaction of lipidextracted sewage sludge.

2021. Journal of cleaner production, 285, Art.Nr. 124895.

doi:10.1016/j.jclepro.2020.124895

Lizenzinformationen: $\underline{\text { CC BY-NC-ND } 4.0}$ 